\title{
Rękopisy amharskie w piśmie arabskim (ağäm) jako świadectwo kultury literackiej muzułmanów etiopskich
}

Zjawisko powstawania rękopisów zawierających teksty w językach afrykańskich spisywane w piśmie arabskim znane jest z wielu obszarów muzułmańskiej Afryki. Zwyczaj notowania języków afrykańskich alfabetem arabskim określany jest mianem ajami (z lokalnymi wariantami), co pochodzi od arabskiego słowa بي "ağami „obcy”, „cudzoziemski”. Na obszarze Afryki Zachodniej przedmiotem wielu studiów były rękopisy w takich językach, jak: hausa, fulfulde, wolof, bambara, songhai, kanuri i innych. Z Afryki Wschodniej znanych jest wiele rękopisów w suahili. O wiele mniej znana jest tradycja rękopisów ajami powstałych w Rogu Afryki, w tym w szczególności w Etiopii. W niniejszym tekście zostaną przybliżone najważniejsze informacje dotyczące rękopisów muzułmańskich w językach Etiopii, przede wszystkim w języku amharskim, w tym kontekst ich powstawania, problemy związane ze stosowaniem arabskiej ortografii do zapisu języka amharskiego oraz tematyka utworów. Amharskie ajami stanowi bowiem istotny i interesujący, choć w dużej mierze należący już do przeszłości, element kultury etiopskich muzułmanów, która przez lata pozostawała nieco w cieniu kultury chrześcijańskich sąsiadów.

\section{Kultura rękopisu ${ }^{1}$ w Etiopii}

W piśmiennictwie dotyczącym Etiopii wielokrotnie podkreślano, iż kraj ten wyróżnia się na tle Afryki Subsaharyjskiej wyjątkowo długą tradycją pisaną. W istocie jednak stwierdzenie to dotyczy przeważnie tylko piśmiennictwa w jednym języku rodzimym, a mianowicie w gə'วz. Najstarsze wyryte w kamieniu inskrypcje $\mathrm{w}$ gəəəz datowane są na III w. n.e. Zapewne wraz z pojawieniem się chrześcijaństwa na terenach Rogu Afryki w połowie IV w. pojawiła się także kultura sporządzania pergaminowych rękopisów i utrwalania na nich tekstów. Do momentu upowszechnienia się w Etiopii druku na przełomie XIX i XX w. rękopisy były jedynym sposobem transmisji wszelkich rodzajów piśmiennictwa. Do naszych czasów zachowało się wiele tysięcy

\footnotetext{
${ }^{1}$ Pojęcia „kultura rękopisu” używam tu w znaczeniu zarówno dosłownym na określenie ogółu zwyczajów w danej kulturze związanej ze sferą rękopisu, tj. ich wytwarzaniem, pisaniem, oprawianiem, dekorowaniem, przechowywaniem itd., ich obiegiem ekonomicznym, zastosowaniami i funkcjami, ale też w znaczeniu nieco bardziej metaforycznym, które przeciwstawia „kulturę rękopisu”, z jednej strony, „kulturze słowa mówionego (oralnej)”, z drugiej zaś - „kulturze druku". Na temat tego drugiego znaczenia por. np. G.L. Bruns, The Originality of Text in a Manuscript Culture, „Comparative Literature” 1980, Vol. 32, No. 2, s. 113-116.
} 
rękopisów gə‘วz, większość z nich pozostaje oczywiście w Etiopii i Erytrei, ale wiele również trafiło różnymi drogami do bibliotek europejskich.

Etiopska chrześcijańska kultura rękopisu była ściśle związana z Etiopskim Kościołem Ortodoksyjnym w tym sensie, że mnisi i księża byli zarówno wyłącznymi wytwórcami, jak i użytkownikami rękopisów, a miejscami ich produkcji i przechowywania były przede wszystkim klasztory i kościoły. Również utrwalane teksty miały w przeważającej części charakter religijny².

Około XVIII i XIX w. podejmowano również próby zapisu języków mówionych w Etiopii, a nie jedynie gə ‘z, który przestał być używany w komunikacji prawdopodobnie jeszcze w starożytności i pozostał jedynie językiem liturgicznym i literackim. Obok rękopisów gə‘’z pojawiły się rękopisy w języku amharskim, zawierające przeważnie krótkie poezje, chrześcijańskie teksty apologetyczne, traktaty magiczno-medyczne czy komentarze do Biblii ${ }^{3}$. Również w tym okresie, zaczęły także sporadycznie powstawać teksty w języku tigrinia, przeważnie w charakterze marginaliów w rękopisach gə‘ $z^{4}$.

W przypadku muzułmanów etiopskich, zdefiniowanie i opisanie ich kultury rękopisu jest z wielu względów bardziej skomplikowane. Można wskazać przynajmniej kilka przyczyn takiego stanu rzeczy.

Po pierwsze, do niedawna jeszcze badania nad etiopskim islamem stanowiły margines całości badaniach nad Etiopią, które koncentrowały się przede wszystkim na kulturze chrześcijańskich ludów zamieszkujących Wyżynę Abisyńską. Można zaryzykować twierdzenie, że ten rodzaj nieco zaburzonej perspektywy w jakiejś mierze odzwierciedlał trwającą przynajmniej do $1974 \mathrm{r}$. faktyczną i prawną marginalizację muzułmanów w Cesarstwie Etiopskim ${ }^{5}$. Taka perspektywa zdołała jednak w pewnej mierze doprowadzić do upowszechnienia się wizji Etiopii jako państwa, w którym istotnym składnikiem tożsamości jest jego starożytne chrześcijaństwo, natomiast islam jest w nim zaledwie lepiej lub gorzej tolerowanym „ciałem obcym”. Chociaż w ostatnich dziesięcioleciach taka wizja Etiopii stała się anachroniczna, ciągle jednak kultura etiopskich muzułmanów jest wyraźnie słabiej zbadana niż ich chrześcijańskich sąsiadów ${ }^{6}$.

\footnotetext{
${ }^{2} \mathrm{Na}$ temat chrześcijańskiej etiopskiej kultury rękopisu zob. głównie A. Bausi, Writing, Copying, Translating: Ethiopia as Manuscript Culture, [w:] Manuscript Cultures: Mapping the Field, eds J.B. Quenzer, D. Bondarev, J.-U. Sobisch, Berlin-Boston 2014, s. 37-77.

${ }^{3}$ L. Ricci, Letterature dell'Etiopia, [w:] Storia delle letterature d'Oriente, ed. O. Botti, Milano 1969, s. 851-853.

${ }^{4}$ Zob. np. G. Lusini, Traditional Land Tenure in Ethiopia: New Documents from Dabra Dehuhūan and Dabra Șegè (Sarā'ē, Eritrea), „Warszawskie Studia Teologiczne” 1999, t. 12, nr 2, s. 145.

${ }^{5}$ Można tu dodać, że również cesarze Etiopii próbowali, i to skutecznie, wpływać na perspektywę badawczą naukowców z euro-amerykańskiego kręgu kulturowego. Jako przykład takich działań można wskazać np. patronat Məniləka II nad wielką kampanią archeologiczną w Aksum prowadzoną przez Niemców na początku XX w. czy ustanowienie przez Haylä Śəllase I dorocznej nagrody za wybitne osiągnięcia w dziedzinie studiów etiopistycznych.

${ }^{6}$ Historię badań nad islamem etiopskim streszcza: H. Ahmed, The Historiography of Islam in Ethiopia, „Journal of Islamic Studies” 1992, Vol. 3, No. 1, s. 15-46.
} 
Po drugie, w przypadku kultury związanej z chrześcijaństwem ortodoksyjnym mamy do czynienia z kulturą względnie jednolitą tj. generalnie mimo pewnego zróżnicowania regionalnego chrześcijan etiopskich łączą obyczaje, typ prowadzonej gospodarki czy obszar zamieszkiwania. Dodatkowo, spójności chrześcijańskiej kultury rękopisu sprzyjały też używanie jednego tylko języka literackiego (gə‘วz) oraz klarowna wertykalna struktura administracji kościelnej. W przypadku islamu w Etiopii mamy do czynienia z o wiele większym wewnętrznym zróżnicowaniem, które dodatkowo przekracza granice Etiopii. Islam etiopskich Somalijczyków zamieszkujących południowo-wschodnią Etiopię będzie zatem znacząco inny od islamu tzw. ğäbärti z Wyżyny Abisyńskiej. Na muzułmanów z prowincji Benəšangul-Gumuz przemożny wpływ wywarło sąsiedztwo z Sudanem ${ }^{7}$, zaś słynne centrum nauki muzułmańskiej, jakim od wieków jest miasto Harär pozostawało w łączności z uczonymi z Jemenu. Jeśli dodać do tego wpływy turecko-egipskie, do dziś widoczne $\mathrm{w}$ islamie erytrejskim, czy zupełnie już współczesną działalność salafickich misjonarzy z Arabii Saudyjskiej, z którą Etiopia utrzymuje ożywione stosunki, otrzymujemy obraz skomplikowany i złożony. Oczywiście sam islam jest również niejako z definicji religią o wiele mniej hierarchiczną, a bardziej zdecentralizowaną niż chrześcijaństwo.

Trzecia kwestia utrudniająca syntetyczne potraktowanie muzułmańskiej kultury rękopisu w Etiopii to wielojęzyczność etiopskiego islamu. Podobnie jak w całym świecie islamu, językiem łączącym wszystkie społeczności muzułmańskie w Etiopii jest oczywiście arabski ${ }^{8}$. Klasyczny język arabski jest językiem kultury wyższej i uczonej, od wieków powstawały w nim na terenie Etiopii dzieła z zakresu teologii, prawa i gramatyki. O historyczności tych tradycji może świadczyć fakt, iż najstarszy rękopis arabski znany z Etiopii pochodzi z 1581 r. ${ }^{9}$ Zarazem jednak arabski ma w Etiopii stosunkowo ograniczoną rolę jako język mówiony, choć w ostatnich latach wskutek masowej migracji zarobkowych Etiopczyków (różnych wyznań) do krajów arabskich znajomość języka arabskiego w mowie znacznie wzrosła. Obszar Etiopii, na którym dominującym wyznaniem jest islam, pokrywa się $\mathrm{w}$ dużym stopniu $\mathrm{z}$ terenami przyłączonymi do Cesarstwa Etiopskiego w drugiej połowie XIX w. Tereny te były wówczas i są dzisiaj dużo bardziej różnorodne językowo i etnicznie niż ma to miejsce w przypadku chrześcijańskiej północy. Wśród muzułmanów etiopskich

\footnotetext{
${ }^{7} \mathrm{O}$ islamie na pograniczu etiopsko-sudańskim zob. np. A. Triulzi, Trade, Islam, and the Mahdia in Northwestern Wallaggā, Ethiopia, „The Journal of African History” 1975, Vol. 16, s. 55-71.

${ }^{8}$ Szerzej na temat statusu języka arabskiego w Etiopii i Rogu Afryki zob. M.-C. Simeone-Senelle, Horn of Africa, [w:] Encyclopedia of Arabic Language and Linguistics, eds K. Versteegh, O. Köndgen, Vol. 2, Leiden 2007, s. 267-275; A. Wetter, Ethiopia, [w:] ibidem, s. 51-56.

${ }^{9}$ A. Gori, Languages and Literatures of the Muslims of the Horn of Africa: Some First General Reflections, [w:] L'Africa, l'Oriente mediterraneo e l'Europa: tradizioni e culture a confronto, ed. P. Nicelli, Milano-Roma 2015, s. 119-126.
} 
język arabski współistnieje zatem z wieloma innymi językami, z których niektóre zaczęły być zapisywane pismem arabskim.

Wreszcie, badania nad muzułmańską kulturą rękopisu w Etiopii utrudnia też sam kontekst, w jakim powstawały i w jakim dziś są przechowywane rękopisy. Rękopisy chrześcijańskie w większości przechowywane są w klasztorach, które są instytucjami publicznymi, a zatem stosunkowo łatwo dostępnymi dla badaczy czy etiopskiego Ministerstwa Kultury i jego agend, które podejmowały próby inwentaryzacji zasobów kościelnych bibliotek. Wiele rękopisów gə‘วz znajduje się ponadto w Bibliotece Narodowej w Addis Abebie oraz w bibliotekach państw zachodnich. Rękopisy muzułmańskie nie były natomiast, częściowo zapewne z przyczyn politycznych, tak chętnie gromadzone przez instytucje publiczne i pozostają w większości bądź w bibliotekach prywatnych lub jako prywatna własność spadkobierców ich oryginalnych twórców i/lub właścicieli, nierzadko rozproszone i przechowywane w wysoce niesprzyjających warunkach ${ }^{10}$.

\section{Specyfika etiopskiego islamu}

Dla zrozumienia kontekstu powstawania rękopisów amharskich w piśmie arabskim konieczne jest wskazanie pewnych charakterystycznych cech etiopskiego islamu. Podobnie jak w innych obszarach Afryki, religia muzułmańska uległa pewnemu dostosowaniu do lokalnych tradycji ${ }^{11}$. W szczególności istotne wydaje się choćby ogólne zdefiniowanie tradycyjnego ${ }^{12}$ (amh. bahalawi) islamu, ponieważ to w tym środowisku rozwijał się ă̆äm.

Według aktualnego stanu wiedzy islam początkowo dotarł na tereny Rogu Afryki dwiema drogami w dwóch różnych okresach ${ }^{13}$. W IX-X w. muzułma-

${ }^{10}$ H.M. Kawo, Islamic Manuscript Collections in Ethiopia, „Islamic Africa” 2015, Vol. 6, s. 192-200.

${ }^{11}$ Ogólnie na temat islamizacji Afryki Subsaharyjskiej zob. S. Piłaszewicz, Religie Afryki, Warszawa 2000, s. 218-240.

${ }^{12}$ Terminu tego należy używać z pewną ostrożnością. Z jednej strony pobrzmiewają w nim echa obecnie raczej odrzucanej dychotomii islamu tradycyjnego, afrykańskiego, bardziej synkretycznego i pokojowo nastawionego (popularna niegdyś koncepcja islam noir) oraz islamu reformistycznego, arabskiego, o nacechowaniu fundamentalistycznym i bojowym. Ponadto, we współczesnej Etiopii termin ten uległ daleko idącej polityzacji i w dyskursie władz zdaje się oznaczać islam w wersji akceptowalnej dla państwa w odróżnieniu od islamu, który jest przedmiotem zainteresowania etiopskich organów bezpieczeństwa. Zagadnienia te omawia szeroko T. Østebø, Islam and State Relations in Ethiopia: From Containment to the Production of a „Governmental Islam”, "Journal of the American Academy of Religion” 2013, Vol. 81, No. 4, s. 1029-1060.

${ }^{13}$ Należy też koniecznie wspomnieć o tradycji, zgodnie z którą pierwsi zwolennicy Proroka znaleźli schronienie na dworze etiopskiego władcy, gdy byli prześladowani na Półwyspie Arabskim przez wrogów ich objawienia. Tradycja ta nie znajduje żadnego potwierdzenia w badaniach naukowych, niemniej przyjmowana jest za pewnik przez wielu etiopskich muzułmanów. Miejscowość Nägaš, w której znajduje się rzekomo założony przez nich meczet oraz groby kilkorga z nich, stała się ważnym centrum pielgrzymkowym, na którego temat zob. m.in. M. Vergari, The Shrine of Nağāš̄ Aș̣am b. Abğar and the Tombs of the Companions of Muhammad (Nägaš, 
nie zdobyli przyczółek na wyspach archipelagu Dahlak (u wybrzeży dzisiejszej Erytrei), skąd przeniknęli na tereny etiopskiej prowincji Təgray, w północnej części Wyżyny Abisyńskiej, by posuwając się w kierunku południowym dotrzeć do wschodniej części prowincji Šäwa. W XIII w. islam zadomowił się na afrykańskim wybrzeżu Zatoki Adeńskiej w portowych miastach Zeyla i Berbera (dzisiejsza Somalia), skąd zaczął rozprzestrzeniać się w kierunku wschodnim, zajmując obszar etiopskiej części Wielkich Rowów Afrykańskich ${ }^{14}$.

Badacze zjawiska konwersji na islam w realiach afrykańskich, tacy jak Nehemia Levtzion czy Humphrey J. Fisher, wyróżniają na ogół trzy różne grupy osób, dzięki którym rozprzestrzeniał się islam. Zarazem, wedle ich oceny, charakter islamu na danym obszarze był w znacznej mierze determinowany przez to, od kogo dana społeczność przyjęła nową religię. Te trzy grupy osób można umownie określić następująco: kupcy, święci mężowie, wojownicy. Wydaje się, że w różnych obszarach, różnych okresach i różnym natężeniu każdy z tych sposobów propagowania islamu miał miejsce w Etiopii.

Wielokrotnie zwracano uwagę, że w Etiopii przez wieki relacja pomiędzy muzułmanami a chrześcijanami miała charakter komplementarny pod względem ekonomicznym: chrześcijanie zajmowali się rolnictwem, muzułmanie - handlem, pasterstwem i rzemiosłem. Szlaki karawanowe, obsługiwane przez muzułmanów, którzy opanowali sztukę wykorzystywania zwierząt jucznych, łączyły chrześcijańskie wyżyny z portami Morza Czerwonego i terenami Sudanu. W muzułmańskich rękach znajdowały się również dwie szczególnie istotne gałęzie handlu: solą i niewolnikami. Podobnie jak miało to miejsce w Afryce Zachodniej na szlakach karawan powstawały ośrodki miejskie w dużej mierze zamieszkałe przez muzułmanów ${ }^{15}$. Współcześnie sugeruje się jednak, że nie należy przeceniać roli kupców w propagowaniu islamu, ponieważ nie mieli oni do tego ani stosownych kwalifikacji religijnych ani też woli, a motywy ich działania były przede wszystkim merkantylne ${ }^{16}$.

Propagowanie islamu na drodze zbrojnej nie miało w Etiopii istotnego znaczenia, ponieważ przemoc na tle wyznaniowym nie zdarzała się często. Istotnym wyjątkiem jest jedynie wojna, jaką Cesarstwo Etiopskie toczyło z koalicją państewek muzułmańskich istniejących na jego obrzeżach w latach w XVI w. Muzułmańska armia, na czele której stanął Aḥmad b. Ibrāhīm al-Gāzī, zaatakowała

Ethiopia), „Ethnorêma” 2016, Vol. 12, http://www.ethnorema.it/pdf/numero\%2012/06\%20Mondofoto.pdf, dostęp 19.07.2017.

${ }^{14}$ F.-X. Fauvelle-Aymar, B. Hirsch, Sur les traces de l'islam ancien en Éthiopie et dans la Corne de l'Afrique, [w:] Espaces musulmans de la Corne de l'Afrique au Moyen Âge: études d'archéologie et d'histoire, eds F.-X. Fauvelle-Aymar, B. Hirsch, Paris 2011, s. 11-26.

${ }^{15}$ R. Pankhurst, A Social History of Ethiopia: The Northern and Central Highlands from Early Medieval Times to the Rise of Emperor Téwodros II, Addis Ababa 1990, s. 49-57.

${ }^{16}$ A. Gori, Contatti culturali nell'Oceano Indiano e nel Mar Rosso e processi di islamizzazione in Etiopia e Somalia, Firenze 2006, s. 11-13. 
Cesarstwo od południowego wschodu i nim została ostatecznie pokonana, zdołała dotrzeć aż do terenów współczesnej Erytrei. Na zajętych przez nią terenach dochodziło wielokrotnie do przymusowych czy przynajmniej wymuszonych konwersji, z których część okazała się mieć trwały charakter ${ }^{17}$.

Jak natomiast pokazują szczegółowe studia dotyczące islamizacji konkretnych regionów Rogu Afryki, kluczową rolę ogrywali w tym procesie „święci mężowie" czyli wędrowni kaznodzieje ${ }^{18}$. Zajmowali się głoszeniem islamu, zakładali szkoły, w których nauczano języka arabskiego, Koranu i prawa muzułmańskiego. Po śmierci wielu z nich stało się obiektami czci jako awliyā, czyli wybrani przez Boga i posiadający nadnaturalne moce.

Gdy w roku 1952 angielski protestancki misjonarz J.S. Trimingham wydał swoją kanoniczną pozycję poświęconą islamowi etiopskiemu, wyróżnił w nim następujące cechy charakterystyczne ${ }^{19}$ : duża rola bractw sufickich, rozwinięty kult świętych oraz obecność przedmuzułmańskich elementów.

Bractwa muzułmańskie (arab. țarīqa, liczba mnoga turuq), oparte na autorytecie nauczycieli, (arab. šayh) co najmniej od XVI w. odgrywały ogromną rolę w szerzeniu islamu na terenach współczesnej Etiopii. Do najpopularniejszych należą Qādirīya i Tiğānīya. Często konwersja na islam była równoznaczna z przystąpieniem do bractwa ${ }^{20}$. Bractwa etiopskie, inaczej niż, na przykład, bractwa w sąsiedniej Somalii, nie sprawowały władzy politycznej nad swoimi członkami, a zajmowały się działalnością edukacyjną, misjonarską i religijną, w tym zwłaszcza koordynowaniem pielgrzymek do grobów świętych mężów.

Wspomniany już kult świętych (awliya $\bar{a}$ ) jest zwyczajem o niewątpliwie sufickiej proweniencji, zarazem jednak ogólne cechy kultu świętych u etiopskich muzułmanów są zaskakująco podobne do ich chrześcijańskich sąsiadów. Istotą kultu świętych jest wiara w ich moc (arab. baraka) wstawiania się u Boga za wiernych, zaś głównym przejawem odbywanie regularnych pielgrzymek do ich grobów, gdzie odprawiane są stosowne rytuały ${ }^{21}$.

\footnotetext{
${ }^{17}$ A. Guérinot, L'islam et l' Abyssinie, „Revue du Monde Musulman” 1917/1918, Vol. 34, s. 15.

${ }^{18}$ Jako przykłady studiów, które dochodzą do takiej właśnie konkluzji wskazać można np.: G. Gemeda, The Islamization of the Gibe Region, Southwestern Ethiopia from c. 1830s to the Early Twentieth Century, ,Journal of Ethiopian Studies” 1993, Vol. 26, s. 63-79 (dla terenów prowincji Käfa); J. Miran, A Historical Overview of Islam in Eritrea, „Die Welt des Islams” 2005, Bd. 45, s. 177-215 (dla Erytrei); E. Wagner, Eine Liste der Heiligen von Harar, „Zeitschrift der Deutschen Morgenländischen Gesellschaft” 1973, Bd. 123, s. 269-292 (dla miasta Harär).

${ }^{19}$ J.S. Trimingham, Islam in Ethiopia, London-New York 1952, s. 225-269. Pomimo zrozumiałej nieaktualności i używanego w niej rażąco rasistowskiego języka, jest to pozycja niezastąpiona. Według teorii Triminghama islam etiopski składa się z trzech warstw: na powierzchni jest tradycyjna muzułmańska ortodoksja, pod nią ezoteryczny islam bractw sufickich, u podstaw zaś przedmuzułmański afrykański komponent.

${ }^{20} \mathrm{~J}$. Abbink, An Historical-Anthropological Approach to Islam in Ethiopia: Issues of Identity and Politics, „Journal of African Cultural Studies” 1998, Vol. 11, No. 2, s. 120. Abbink sugeruje, że popularność bractw w Afryce wynika częściowo z faktu obecności w nich rytuałów inicjacyjnych, które odgrywały istotną rolę w wierzeniach przedmuzułmańskich.

${ }^{21}$ M. Zeleke, „We Are the Same but Different”: Accounts of Ethiopian Orthodox Christian Adherents of Islamic Sufi Saints, „Journal for the Study of Religion” 2014, Vol. 27, No. 2, s. 198-201.
} 
Natomiast jako elementy przedmuzułmańskie, które zostały inkorporowane do tradycyjnego etiopskiego islamu wskazać można: powszechne występowanie kultów opętania (zar), wiara w różnego rodzaju duchy, zwyczaje związane z magią i wróżbiarstwem, obecność jedynie powierzchownie zislamizowanych ceremonii agrarnych. Wygląd i stopień natężenia tych „pogańskich” elementów przedstawia się różnie w różnych grupach etnicznych.

\section{A ̆gäm - historia badań i charakterystyka}

Spośród języków używanych w Etiopii, istnienie rękopisów ă̆äm zostało potwierdzone dla oromo ${ }^{22}, \operatorname{argobba}^{23}$ i səlți ${ }^{24}$, natomiast przedmiotem pogłębionych studiów (do których zaliczyć można też publikację tekstów) stały się jedynie rękopisy ăgäm $\mathrm{w}$ językach harari ${ }^{25} \mathrm{i}$ amharskim. Rękopisy w języku harari są przy tym zjawiskiem zupełnie wyjątkowym na tle innych rękopisów z Rogu Afryki, zarówno ze względu na ich stosunkowo dawny wiek (najstarsze pochodzą z początku XVIII w.), jak i różnorodność zapisanych w nich tekstów ${ }^{26}$.

Rękopisy ăgäm w języku amharskim są ciągle stosunkowo słabo zbadane. Ani jeden dłuższy tekst nie został w całości krytycznie wydany. Pionierem badań nad ă̆äm był Enrico Cerulli (1898-1988) ${ }^{27}$. Pierwsze dłuższe studium na temat ăgäm i etiopskich rękopisów muzułmańskich napisał Abraham Johannes Drewes (1927-2007) ${ }^{28}$. Krótki, ale istotny artykuł, poświęcił temu zagadnieniu Alula Pankhurst ${ }^{29}$. Zwiększenie zainteresowania tą tematyką nastąpiło

${ }^{22}$ Język oromo (oromíffáa) - język z grupy kuszyckiej, prawdopodobnie największy język w Rogu Afryki używany przez ok. 18 milionów ludzi jako rodzimy. Większość użytkowników mieszka w południowej i centralnej Etiopii. Użytkownicy oromo są bardzo zróżnicowani pod względem kulturowym i wyznaniowym. Zapisywany alfabetem łacińskim.

${ }^{23}$ Język argobba - język z grupy semickiej, Znajduje się obecnie na skraju. Używany w kilku wsiach w regionie Wällo. Wszyscy użytkownicy są muzułmanami.

${ }^{24}$ Język səlți - język z grupy semickiej, należący do podgrupy języków gurage. Używany przez ok. 800 tysięcy ludzi na wschód od jeziora Zway. Większość użytkowników to muzułmanie. Nieliczne drukowane teksty są zapisywane pismem etiopskim.

${ }^{25}$ Język harari - język z grupy semickiej, używany przez ok. 20 tysięcy mieszkańców miasta Harär (bądź ich potomków), które co najmniej od XVI w. było najważniejszym ośrodkiem duchowym i intelektualnym islamu w Rogu Afryki.

${ }^{26}$ Zob. np. G. Banti, The Literature of Harar until the End of the 19th Century, [w:] L'islam in Etiopia: bilanci e prospettive, eds A. Gori, B. Scarcia Amoretti, Napoli 2010, s. 149-182.

${ }^{27}$ E. Cerulli, Canti amarici dei musulmani di Abissinia, „Rendiconti della Reale Accademia Nazionale dei Lincei” 1926, ser. 6, Vol. 2, s. 433-447 (dalej cytowane jako CerCanti). Dla ścisłości, Cerulli nie pisze wprost, że publikowane przez niego teksty zostały napisane alfabetem arabskim. Stylistycznie są one jednak bardzo podobne do utworów, co do których mamy pewność, że powstały jako ă̆äm.

${ }^{28}$ A.J. Drewes, Classical Arabic in Central Ethiopia: English Text of the Paper Read on 11 December 1975 for the „Oosters Genootschap in Nederland”, Leiden 1976 (dalej cytowane jako DrArabic).

${ }^{29}$ A. Pankhurst, Indigenising Islam in Wällo: Ajäm, Amharic Verse Written in Arabic Script, [w:] Proceedings of the Eleventh International Conference of Ethiopian Studies, Addis Ababa, April 
po roku 1991. W wyniku przemian politycznych po raz pierwszy w dziejach Etiopii muzułmanie zostali w pełni zrównani ze swoimi chrześcijańskimi rodakami. Znalazło to odzwierciedlenie $\mathrm{w}$ dużo większej liczbie studiów poświęconych etiopskiemu islamowi. Spośród czynnych obecnie badaczy zagadnieniem amharskiego ağäm zajmują się między innymi Andreas Wetter ${ }^{30}$ i Alessandro Gori ${ }^{31}$. Zaczęły pojawiać się również prace o tej tematyce autorstwa uczonych etiopskich ${ }^{32}$.

Przed omówieniem treści amharskich tekstów ă̆äm warto poświęcić jeszcze nieco uwagi ich językowi oraz miejscu, gdzie większość z nich (przynajmniej tych dotychczas znanych) powstała, czyli odpowiednio językowi amharskiemu i prowincji Wällo.

Język amharski jest (po arabskim) drugim największym językiem semickim. Dla ok. 18 milionów mieszkańców Etiopii jest on pierwszym językiem, a niemal wszyscy znają go w jakimś stopniu, ponieważ pełni funkcję języka komunikacji międzyetnicznej oraz języka roboczego ${ }^{33} \mathrm{w}$ kraju. Pierwotnie amharski używany był głównie w centralnej części Wyżyny Abisyńskiej, która była zarazem tradycyjnym rdzeniem Cesarstwa Etiopskiego, gdzie amharski był językiem dworskim ${ }^{34}$. Jednak prowadzona od XIV w. polityka zasiedlania nowo przyłączonych obszarów kolonistami z tego regionu doprowadziła do znacznej ekspansji amharskiego. Przez większość XX w. amharski był głównym, jeśli nie jedynym językiem edukacji i administracji w Etiopii ${ }^{35}$.

Piśmiennictwo w języku amharskim rozwija się od XIX w., choć sporadycznie utrwalano teksty amharskie już wcześniej. Istnieje również bogata oratura, przy czym ta kwitnie głównie na obszarach amharskiego „matecznika”, tj. prowincji Goğğam, Bägemdər, Lasta, Wällo i Šäwa. Z wyjątkiem omawianych w niniejszym artykule tekstów, do zapisu amharskiego używano zawsze pisma etiopskiego.

1-6 1991, Vol. 2, eds B. Zewde, R. Pankhurst, T. Beyen, Addis Ababa 1994, s. 257-273 (dalej cytowane jako PanInd).

${ }^{30}$ A. Wetter, Rhetoric Means of a Didactic Amharic Poem from Wärrä Babbo, „Aethiopica” 2012, Vol. 15, s. 176-203 (dalej cytowane jako WetRhet).

${ }^{31}$ A. Gori, Lingua, scrittura e religione in Etiopia: un testo islamico amarico in grafia araba, [w:] XII Incontro Italiano di Linguistica Camito-Semitica (Afroasiatica): atti, ed. M. Moriggi, Rubbettino 2007, s. 243-254 (dalej cytowane jako GorLin).

${ }^{32}$ K. Abdulwehab, The Kašf al-Ġumma by Šayh Talha b. Ğa 'far (d. 1935): a Messianic and Polemical Amharic-Ağäm Text, [w:] Essays in Ethiopian Manuscript Studies: Proceedings of the International Conference Manuscripts and Texts, Languages and Contexts: The Transmission of Knowledge in the Horn of Africa, Hamburg, 17-19 fuly 2014, eds A. Bausi, A. Gori, D. Nosnitsin, E. Sokolinski, Wiesbaden 2015, s. 309-324 (dalej cytowane jako KemKašf).

${ }^{33}$ Taka fraza (amh. yä-səra $q^{w} a n q^{w} a$ ) pojawia się w konstytucji Etiopii. Żaden język nie ma w Etiopii statusu języka urzędowego.

${ }^{34}$ Dlatego też był on określany w gə‘วz jako lasanä nəguś czyli „język króla” w odróżnieniu od lasanä tarik, czyli „języka historii”, tj. języka literackiego, jakim był gə‘əz.

${ }^{35}$ D. Appleyard, M. Orwin, The Horn of Africa: Ethiopia, Eritrea, Djibouti and Somalia, [w:] Language and National Identity in Africa, ed. A. Simpson, Oxford 2008, s. 271-276. 
Jak wspomniano, jedną z prowincji Etiopii, gdzie amharski był i do dziś pozostaje językiem dominującym, jest prowincja Wällo. Zarówno pod względem kulturowym, jak i geograficznym jest to typowy region pogranicza.

Od północy graniczy z niemal jednolicie ortodoksyjnie chrześcijańskim regionem Təgray, od południa z terenami prawie całkowicie zislamizowanymi. Islam i chrześcijaństwo sąsiadują i przenikają się tam od wieków ${ }^{36}$.

Istnieje wiele tradycji ustnych dotyczących pojawienia się islamu w Wällo. Przypisują one zaszczepienie islamu grupom nauczycieli (arab. 'ulamā') wywodzącym się z ğäbärti, Jemenu lub z północnej części Šäwa. Niezależnie od miejsca ich przybycia, tradycje zgadzają się w tym, iż przybycie islamu wiązało się z działalnością wędrownych uczonych. Na XIX w. przypada znaczny rozkwit islamu w Wällo, związany z pojawieniem się na terenie prowincji bractw sufickich ${ }^{37}$.

Przez wieki o specyfice Wällo decydowała wyraźna tożsamość muzułmańska połączona jednak z istotną obecnością chrześcijańską. Dla zilustrowania, rządzący Wällo od końca XVIII w. do 1878 r. władcy z dynastii Mammädočč z jednej strony nosili tytuł imamów i demonstrowali gorliwość w promowaniu islamu, z drugiej zaś często brali sobie za żony kobiety z chrześcijańskich rodów, niekiedy też czasowo przechodzili na chrześcijaństwo ${ }^{38}$.

Co istotne, islam w Wällo znajdował się pod przemożnym wpływem ośrodka w Harerze. Oba regiony były połączone więzami handlu, również 'ulamā' $\mathrm{z}$ jednego $\mathrm{z}$ nich nauczali $\mathrm{w}$ drugim, centra pielgrzymkowe w Wällo miały świętych patronów z Hareru i odwrotnie ${ }^{39}$. Ponieważ zaś w Harerze, jak już wspomniano, istniała długa tradycja spisywania tekstów w języku miejscowym, można postawić hipotezę, że to właśnie dzięki tym kontaktom zrodziła się w Wällo idea spisywania tekstów amharskich w piśmie arabskim.

\section{Język tekstów ă̆äm}

Trudno stwierdzić, czy wybór pisma arabskiego do zapisu omawianych tu tekstów był świadomą decyzją czy też koniecznością, innymi słowy, czy ich autorzy/kopiści znali pismo etiopskie, czy też nie. W czasach, gdy powstawały znane nam amharskie ăgäm, w Etiopii nie istniała jeszcze świecka edukacja, a stosowania pisma etiopskiego można się było nauczyć jedynie w szkołach

${ }^{36}$ H. Rubinkowska-Anioł, Granice pomiędzy chrześcijaństwem a islamem w Etiopii, „Afryka” 2015, t. 41 , s. $58-59$.

${ }^{37} \mathrm{H}$. Ahmed, Islam in Nineteenth-Century Wallo, Ethiopia: Revival, Reform, and Reaction, Leiden-Boston 2001, s. 60-63.

${ }^{38}$ É. Ficquet, La mixité religieuse comme stratégie politique. La dynastie des Māmmadoč du Wallo (Éthiopie centrale), du milieu du XVIIIe siècle au début du XXe siècle, „Afriques” 2010, No. 1, http://afriques.revues.org/533, dostęp 27.07.2017.

${ }^{39} \mathrm{H}$. Ahmed, Harar-Wallo Relations Revisited: Historical, Religious and Cultural Dimensions, „African Study Monographs” 2010, Suppl. 41, s. 111-117. 
przykościelnych, do których muzułmanie oczywiście nie uczęszczali. Zarazem można sobie wyobrazić, że pismo etiopskie było dla muzułmanów symbolem chrześcijańskiej opresji i z tego względu mogli nie chcieć go stosować ${ }^{40}$.

Amharski i arabski są językami odlegle spokrewnionymi, jednak ich systemy fonologiczne różnią się znacznie. Zasób spółgłoskowy amharskiego jest uboższy niż literackiego arabskiego, nie występują w nim choćby spółgłoski gardłowe ani międzyzębowe. Spółgłoski nieobecne w arabskim oddawano przez modyfikację znaków dla spółgłosek zbliżonych brzmieniowo, np. amharskie [g] zapisywane jest przez zmodyfikowaną literę kāflub (rzadziej) jīm. Bardzo częsta (bo występująca w wielu morfemach gramatycznych) spółgłoska [č] jest regularnie oddawana przez zmodyfikowany znak sin.

Samogłoski, podobnie jak w arabskim, oddawane są przez znaki wokalizacyjne oraz matres lectionis. I tak na przykład amharskie [o] zapisywane jest przez $w \bar{a} w$, dodatkowo może stać nad nim fatha lub też ḍmma nad poprzedzającą je spółgłoską. Amharskie [ə] oddawane jest przez kasra lub fatha. Tak jak w arabskim, šadda oznacza geminację spółgłoski. Przy obecnym stanie badań można odnieść wrażenie, że ortografia tekstów ağäm nie była zestandaryzowana i zależała w dużej mierze od preferencji kopisty/autora.

Od strony leksykalnej daje się zauważyć obecność bardzo licznych zapożyczeń z języka arabskiego, co oczywiście nie jest w tym kontekście zaskakujące. Skądinąd arabski jest jednym z głównych źródeł zapożyczeń w języku amharskim $^{41}$. Zapożyczone rzeczowniki zachowują się w pełni według reguł języka amharskiego. Na przykład określenie na towarzyszy Proroka brzmi 'asḥabočč, gdzie -očč to amharska końcówka liczby mnogiej. Interesującym zjawiskiem jest zapożyczanie $\mathrm{z}$ arabskiego czasowników i dostosowywanie ich do amharskiej fleksji, nawet jeśli w amharskim istnieje odpowiednik. W jednym $\mathrm{z}$ tekstów ${ }^{42}$ słowo „czytać” oddane jest przez arabskie qärra a nie amharskie anäbbäbä.

Występuje także zjawisko zapożyczania rdzeni z języka arabskiego i derywowania od nich rzeczowników według reguł amharskiego słowotwórstwa. Przykładowo, w rękopisie IES $4610^{43}$ znajdujemy rzeczownik 'affäsasär „objaśnienie”, utworzony od niewystępującego w amharskim czasownika fasara przy użyciu amharskiego wzorca $\mathrm{aC}_{1} \mathrm{C}_{1} \ddot{a}_{2} \mathrm{aC}_{2} \mathrm{ä}_{3}$.

${ }^{40}$ Kwestia ta wynikła także podczas kampanii alfabetyzacyjnych prowadzonych przez władze etiopskie w drugiej połowie XX w. Wielu muzułmanów z takiego właśnie powodu odrzucało pomysł zapisu swoich języków w piśmie etiopskim. I tak np. używane niemal wyłącznie przez muzułmanów języki afar czy Somali zapisywane są w piśmie łacińskim. Są jednak i kontrprzykłady, np. język təgre mówiony w Erytrei używa pisma etiopskiego, mimo że ogromna większość jego użytkowników to muzułmanie.

${ }^{41} \mathrm{Na}$ ten temat zob. W.K. Brzuski, Zapożyczenia arabskie $w$ dawnym $i$ współczesnym języku arabskim, Warszawa 1983. Należy podkreślić, że teksty ağäm w ogóle nie były uwzględniane w amharskiej leksykografii.

${ }^{42}$ WetRhet, s. 192.

${ }^{43}$ Składam serdeczne podziękowanie prof. Alessandro Gori z Uniwersytetu w Kopenhadze za zgodę na publiczną prezentację fragmentów tego rękopisu. 
Inną godną odnotowania cechą języka tekstów amharskich spisywanych w piśmie arabskim jest fakt, że zawierają one elementy dialektalne, nieobecne we współczesnym standardowym języku amharskim, którego podstawą jest dialekt prowincji Šäwa. Badania językoznawcze nad dialektami amharskimi nie są dobrze rozwinięte, sam amharski zaś uchodzi za język o stosunkowo niewielkim zróżnicowaniu dialektalnym. Tym cenniejsze są zaświadczone w tekstach $a \breve{g} \ddot{a} m$ językowe swoistości.

\section{Teksty ăgäm - autorstwo, forma, tematyka}

Dotychczas omawiane w nauce teksty ăgäm powstały w drugiej połowie XIX i pierwszej połowie XX w. Dwa z nich mają ustalone autorstwo. Autorem Kašf al-ġumma jest šayh Ṭalha b. Ğa'far (ok. 1853-1936), wybitny kaznodzieja i przywódca duchowy społeczności muzułmańskiej. Autorem tekstu opublikowanego przez A. Wettera jest Bašir 'Umar, o którym brak jakichkolwiek informacji. Większość tekstów pochodzi z prowincji Wällo, niektóre jednak ${ }^{44}$ zostały zebrane wśród ludu Səlṭi, którzy zamieszkują Region Narodów, Narodowości i Ludów Południa.

Wszystkie omawiane teksty mają formę poetycką. Choć zagadnienie to nie zostało dotychczas w ogóle podjęte, daje się zauważyć, iż niekiedy teksty ağäm oparte są na rygorach formalnych ustnej poezji amharskiej. Przykładowo, dwuwiersz:

\section{säyyədənna räsul səməh mäțaffäțu \\ wätät əndäț̈tțu mar əndalammäț $u^{45}$}

[Nasz] Pan i Prorok - smak twego imienia

Jest niby picie mleka, niby kosztowanie miodu.

składa się z wersów o długości dwunastu sylab, zakończonych rymem z aliteracją, która to miara określana jest tradycyjnie jako dämbäñ̃na bet. Można zatem ostrożnie postawić tezę, iż źródeł muzułmańskiej poezji należy szukać raczej $\mathrm{w}$ tradycyjnej oraturze amharskiej niż w naśladowaniu arabskich wzorów ${ }^{46}$.

W Etiopii muzułmańską poezją religijną w lokalnych językach, obficie okraszoną wtrętami arabskimi, określa się przeważnie terminem mänzuma (od arabskiego (موظنم). Ten rodzaj poezji przeznaczony jest do śpiewania. Tradycyjnie wykonywano te pieśni z towarzyszeniem bębnów i klaskania podczas Ramadanu, ważnych świąt czy spotkań bractw sufickich. Współcześnie są one również nagrywane $\mathrm{z}$ towarzyszeniem instrumentów elektronicznych. Teksty te stanowią ważny element pobożności muzułmanów etiopskich, $\mathrm{w}$ dawnych czasach pełniły również rolę w propagowaniu islamu, w przystępnej

\footnotetext{
${ }^{44}$ GorLin, DrArabic.

${ }^{45}$ CerCanti s. 249.

${ }^{46}$ Takie naśladowanie postuluje jednak A. Gori, według którego tekst z GorLin wzorowany jest na arabskiej konwencji poetyckiej muhammasa.
} 
i atrakcyjnej formie objaśniając jego doktrynę ${ }^{47}$. Jest wielce prawdopodobne, że znane nam rękopisy ăgäm są utrwaloną na piśmie wersją takich właśnie, pierwotnie wykonywanych ustnie kompozycji, względnie ich autografem.

Przykładem tekstu o charakterze dydaktycznym i misjonarskim jest tekst omawiany przez A. Wettera. Według badacza, tekst ten jest określany przez jego użytkowników jako tawhìd i zawiera wykład podstawowych zasad wiary muzułmańskiej, takich jak pięć filarów islamu, sześć dogmatów wiary, imiona i rola aniołów. Oprócz tego zawiera liczne napomnienia moralne i opis kar dla grzeszników ${ }^{48}$. Z takiej treści można wnioskować, iż tekst miał służyć szerzeniu islamu. Zapewne też z tego względu został spisany po amharsku, ponieważ przez ten język można było najłatwiej trafić do szerokich rzesz ludności. Użycie formy poetyckiej nadawało też zapewne tekstowi walor mnemotechniczny, dzięki czemu świeżo nawróceni na islam mogli z łatwością zapamiętać narzucane przez religię prawdy wiary i obowiązki. Na jego homiletyczno-dydaktyczny charakter wskazuje częste używanie form rozkaźnikowych oraz adresatywnych w rodzaju $s^{w}$ ahibočč $e^{49}$ „[o] moi przyjaciele”.

Z kolei poemat Kašf al-g்umma, będący przedmiotem rozważań Kemala, nawiązuje do konkretnych wydarzeń historycznych. Otóż w 1878 r., z inicjatywy cesarza Jana IV, miały miejsce prześladowania muzułmanów zmierzające od ich przymusowej konwersji. Chociaż represje te nigdy nie osiągnęły znacznych rozmiarów ani nie przyniosły trwałego skutku, poważnie zaburzyły jednak życie etiopskich wyznawców islamu. Ponadto, od roku 1884 do 1889 trwała wojna cesarstwa z sudańskimi mahdystami. Oba te wydarzenia znalazły odzwierciedlenie w poemacie.

Tekst zagrzewa czytelników (lub słuchaczy?) do stawiania oporu chrześcijańskiej przemocy, wychwala Mahdiego i wzywa do poparcia go. Potępia także muzułmańskich uczonych, którzy nie stoją po stronie Mahdiego i są zbytnio zainteresowani życiem ziemskim. W tekście znajduje się szereg ogromnie ciekawych aluzji do życia muzułmanów w Cesarstwie. Przykładowo, wiadomo powszechnie, iż muzułmanie byli wyłączeni ze skomplikowanego quasi-feudalnego systemu użytkowania ziemi rolnej, co oczywiście interpretuje się jako ich dyskryminację. Talha b. Ğa'far pisze natomiast ${ }^{50}$ o posiadaniu ziemi i byciu dzierżawcą (amh. balagär) jako jarzmie, którego muzułmanie powinni się wystrzegać. Godnym odnotowania jest fakt, iż autor konsekwentnie używa wobec chrześcijan określenia „Amharowie” (amara), co rzuca ciekawe światło na użycie tego wieloznacznego - tak dawniej jak dzisiaj - epitetu.

\footnotetext{
${ }^{47}$ PanInd, s. 261-262.

${ }^{48}$ WetRhet, s. 13.

${ }^{49}$ Jest to, oczywiście, zapożyczenie arabskiego słowa șāḥib.

${ }^{50}$ Kem Kašf, s. 319.
} 
Drewes w swoim artykule podaje kilka przykładów tekstów używanych podczas ceremonii $d i k r$ (w amharskiej wymowie $z i k r$ ). Te wywodzące się z sufickiego mistycyzmu ceremonie polegające na litanijnym powtarzaniu imion Boga lub chwalących go formuł towarzyszą pielgrzymkom go grobów świętych mężów, ślubom, pogrzebom czy dorocznym świętom z muzułmańskiego kalendarza. Teksty cytowane przez Drewesa mieszają gotowe frazy przejęte $\mathrm{z}$ arabskiego z językiem amharskim. Można je zaklasyfikować jako teksty o charakterze liturgicznym. Interesujące jest, że tego rodzaju teksty funkcjonowały także na terenach, gdzie amharski nie był podstawowym językiem codziennej komunikacji ${ }^{51}$. Potwierdza to sygnalizowaną już tezę, iż wybór języka amharskiego podyktowany był chęcią dotarcia z misyjnym przesłaniem do możliwie najszerszych grup ludności.

Wreszcie krótkie fragmenty zebrane przez Pankhursta i Cerullego są różnorodne w treści. Większość zebranych przez Cerullego utworów opiewa Proroka oraz inne postaci z Koranu bądź przekazuje moralne nauki islamu. Szczególnie ciekawe są w tym zbiorku wiersze zawierające polemikę antychrześcijańską, w których wytyka się chrześcijanom (nota bene, również określanym terminem amara) m.in., iż „wykrawają kawałek drewna i mówią mu »zmiłuj się nade mną "52 lub że w istocie czczą wielu Bogów („czyż Bóg jest wioską?”53).

\section{Podsumowanie}

Teksty ăgäm dopiero od niedawna są przedmiotem zainteresowania naukowego. Dotychczas zebrany i opublikowany materiał jest bardzo skąpy i nie pozwala na wyciąganie zbyt daleko idących wniosków. Wydaje się, że powstawanie amharskich tekstów ağäm było zjawiskiem ograniczonym chronologicznie (od połowy XIX w. do ok. 1920 r.) i terytorialnie (prowincja Wällo). Wybór języka amharskiego wynikał z faktu, iż jako język wehikularny lepiej sprawdzał się jako nośnik nowych treści religijnych niż znany tylko wąskim elitom arabski. Użycie pisma arabskiego do jego zapisu było raczej praktyczną koniecznością niż świadomym wyborem. Teksty ağäm są niezastąpionym źródłem to badań nad społecznością muzułmańską w tym konkretnym miejscu i czasie, gdyz - jak ilustruje to zaprezentowany materiał - są odzwierciedleniem jej postaw religijnych, a także problemów jako grupy mniejszościowej.

\footnotetext{
${ }^{51}$ DrArabic, s. 185.

${ }^{52}$ CerCanti, s. 250

${ }^{53}$ Ibidem, s. 252.
} 